\title{
CONSUMER PROTECTION IN THE SUPPLY OF SERVICES: A COMPARATIVE STUDY BETWEEN THE CONSUMER PROTECTION ACT 1999 AND ISLAMIC LAW
}

\author{
Elistina Abu Bakar* \\ Naemah Amin**
}

\begin{abstract}
The Consumer Protection Act 1999 (CPA) that came into force on 15 November 1999 represents a milestone in consumer protection in Malaysia. ${ }^{1}$ It has several important provisions, some of which are more beneficial than those found in the law of contract and law of tort since its objective is specifically to protect the interest of consumers. The statute is applicable to both goods and services but the provisions on services are very important because previously the laws regulating the supply of services seem to be left behind compared to those regulating
\end{abstract}

\footnotetext{
* Lecturer, Centre of Excellence for Sustainable Consumer, Faculty of Human Ecology, University Putra Malaysia.

** $\quad$ Associate Professor, Ahmad Ibrahim Kulliyyah of Laws, International Islamic University Malaysia.

1 It is based on the Consumer Guarantees Act 1993 (New Zealand), the Trade Practices Act 1974 (Australia), the Consumer Protection Act 1996 (Statute of Saskatchewan), the Supply of Goods and Services Act 1982 (United Kingdom) and the Consumer Protection Act 1987 (United Kingdom).
} 
goods. The aim of this paper is to examine the relevant provisions of the CPA and make a comparative study with the protection available under the Islamic law of mu'ämalät. The central discussions are on section 53, section 54 and Part IX of the CPA since they deal specifically with the supply of services. The liabilities of the service providers are scrutinised as well as consumers' rights of redress.

Keywords: Consumer protection, supply of services, Islamic law.

\section{INTRODUCTION}

'Consumer protection' refers to safeguards against malpractice and exploitative techniques by suppliers of goods or services that adversely affect consumers. $^{2}$ There are three important aspects of consumer protection. $^{3}$ The first is the physical protection of consumers such as measures to protect consumers against injurious products or services. ${ }^{4}$ The second is the protection of the economic interest of consumers, which includes measures to protect them against deceptive and other unfair trading practices. ${ }^{5}$ This may be referred to situations in which service providers fail to provide services as expected or they use sub-

$2 \quad$ Anwarul Yaqin, Law and Society in Malaysia, ILBS, 1996, p. 77.

3 Mohanty, "Consumer protection: a challenging task" in Consumer protection and legal control, edited by P. Leelakrishnan, Eastern Book Company, Lucknow India, 1984, p. 24-30.

$4 \quad$ For example, Part III of the Consumer Protection Act 1999 (Act 599), the Sale of Drugs Act 1952 (Act 368), the Medicine (Advertisement and Sale) Act 1956 (Act 290), the Food Act 1983 (Act 281), the Electrical Inspectorate Act 1983 (Act 277), the Electricity Supply Act 1990 (Act 447), the Pesticides Act 1974 (Act 149), the Poisons Act 1952 (Act 366) and the Radioactive Substances Act 1968 (Act 17).

$5 \quad$ For example, The Trade Discription Act 1972 (Act 87), the Price Control Act 1946 (Act 121), the Sale of Goods Act 1957 (Act 382), the Hire Purchase Act 1967 (Act 212), the Weights and Measures Act 1972 (Act 71), Part II of the Consumer Protection Act 1999. 
standard materials. The third is the protection of public interest. It covers measures to prevent abuse of monopoly position so that consumers can have lots of choice in term of variety, prices and quality of the products and services. In comparison with the degree of consumer protection provided in the more advanced countries such as the USA and the European Union, Malaysia still has a long road to travel. The area that seems to be most neglected is consumer protection in the service industry despite the fact that services are equally as important as goods and regularly used by consumers in their daily life. It is hoped that the CPA can provide better legal protection for consumers compared to the existing laws of contract and tort.

Comparatively, Islam provides a complete way of life ${ }^{6}$ and its values of truth, justice and brotherhood protect consumers in their daily transactions. There are two obligations imposed on mankind which are the rights of man ( $h u q \bar{u} q$ al-'ibād) which regulate the relationship between two parties according to their wills and the rights of God (huqūqulläh) in which the law provides duties owed to other persons generally. ${ }^{7}$ These two obligations have been outlined in such a way as to protect consumers on all occasions whether they are the parties to the transactions or not. The rights of God and the rights of man have a greater resemblance to right in rem and right in personam as conceived by the common law system. ${ }^{8}$

However, Islam does not provide a specific area of consumer protection ${ }^{9}$ since the consumer's legal rights derived primarily from the Islamic law of $m u$ 'ämalät outlines many principles and sets many ethical standards that provide sufficient protection to consumers. For example,

$6 \quad$ Al-Qur'ān, Sūrah Al-Mā'idah 5:3.

$7 \quad$ Liaquat Ali Khan Niazi, Law of Contract, Ali Khan Niazi Research Cell, Dyal Sing Trust Library, 1991, p. 22; Ibn 'Ashūr, Treatise on maqāṣid al-shari'‘ah, translated by Mohamed El-Tahir El-Mesawi. The International Institute of Islamic Thought, Washington, 2006, p.226.

8 Saqlain Masoodi, "Civil liability in English and Islamic laws: a comparative view,” Islamic and Comparative Law Review, Vol. xii, no. 1, 1992, p. 40.

$9 \quad$ Liaquat Ali Khan Niazi, Law of Contract, Ali Khan Niazi Research Cell, Dyal Sing Trust Library, 1991, p. 54. Liaquat was in the opinion that the Islamic law of contract is sufficient in giving protection to consumers. 
Allah (swt) imposes obligations such as the trust to transact honestly and justly based on the principle of Islamic brotherhood. ${ }^{10}$

\section{THE TYPES OF 'SERVICES' UNDER THE CPA}

Service is defined to include:

"any rights, benefits, privileges or facilities that are or are to be provided, granted or conferred under any contract but does not include rights, benefits or privileges in the form of the supply of goods or the performance of work under a contract of service."11

It is evident from the above definition that the term 'services' is defined broadly to include 'any' contract except in the two instances mentioned above. ${ }^{12}$ Therefore, there are three types of consumer services that are clearly within the ambit of the CPA. ${ }^{13}$ Firstly, are pure services contracts which do not result in any tangible product, such as parking, entertainment, recreation etc. Secondly, are services which produce tangible products such as a tailor who produces dresses or a dentist who produces dentures. ${ }^{14}$ Thirdly, are services associated with

10 Al-Qur’ān, Sūrah Al-Humazah 104:1-4, Sūrah Al-Baqarah 2: 188, Sūrah Al-Raḥmān 55:9, Sūrah Al-An 'àm 6:152, Sūrah Al-Isrā' 17:35, Sūrah AlBaqarah 2:177, Sūrah Al-Isrä' 17:34, Sūrah Al-Mu'minūn 23:8, Sūrah Al-Baqarah 2:190.

11 Section 3(1) of the CPA.

12 In addition, the CPA does not apply to services provided by professionals, housing developers and healthcare services (section 2(2) of the CPA). Nonetheless, if compared with the definition of services in section 4(1) of the Trade Practices Act 1974 (Australia) and section 2 of the Consumer Guarantees Act 1993 (New Zealand), the CPA defines services broadly without mentioning any specific services as listed in these two legislations.

13 By virtue of the definition of consumer in section 3(1) of the CPA, services are confined to "services of a kind ordinarily acquired for personal, domestic or household purpose, use or consumption.”

14 Section 60, section 62 and section 64 of the CPA. These sections on remedies give a great reliance on the products resulting from the 
the supply of goods or materials which are normally provided by a skilled tradesman such as a plumber, an electrician and a repairer, all of whom will use some material article in addition to the skill they exercise. This should be distinguished from services which are merely incidental to the supply of goods, for example a contract for the purchase and installation of a water heater or kitchen cabinet which are excluded from the definition of services.

Under Islamic law, the services can also be categorised under several types. Each type is governed by specific rules. The first type is known as istisnn $\bar{a}^{c}$ which means the giving of the order to a workman to make a definite thing with the agreement to pay a definite wage or price of that thing when made. ${ }^{15}$ Istisn $\bar{a}^{c}$ is similar to the second type of services under the CPA. The second type of services is known as the contract of hire (ijärah), which is a hire of a workman to do a job. It is a sale of usufruct and also includes a contract for rendering services such as mechanics. ${ }^{16}$ There are two types of service provider under the contract of hire. The first type is private hire (ajir khässs) in which the worker is employed to work for the hirer alone such as a servant. ${ }^{17}$ The other one is common hire (ajī mushtarak) in which the worker is not restricted to work for anyone other than the hirer. ${ }^{18}$ The examples are a

services. Section 54 provides a guarantee that any product resulting from the services will be fit for its purpose.

Liaquat Ali Khan Niazi, Law of contract, Ali Khan Niazi Research Cell, Dyal Sing Trust library, 1991, p. 218. Nevertheless, Hanafīs considered istisna $\bar{a}^{r}$ as a contract of sale rather than services. See Wahbah alZuhailī, al-Fiqh al-Islāmī wa-ädillatuhū, vol. iv, translated by Md Akhir Haji Yaacob, Dewan Bahasa dan Pustaka, Kuala Lumpur, 1995, p. 649.

Liaquat Ali Khan Niazi, Law of contract, Ali Khan Niazi Research Cell, Dyal Sing Trust library, 1991, p. 296. There are two types of contract of hire (Ijārah). The first one is the sale of usufruct such as renting a house or vehicle. The second type is hire for labour. See also Wahbah al-Zuhailī, al-Fiqh al-Islāmī wa-ādillatuhū, vol. iv, translated by Md Akhir Haji Yaacob, Dewan Bahasa dan Pustaka, Kuala Lumpur, 1995, p. 763.

This type of contract may be categorized as a contract of service or employment contract which is excluded from the definition of services in the CPA.

Sayid Sabiq, Fikih Sunnah, vol. 13, translated by H. Kamaluddin A. Marzuki, Victory Agencies, Kuala Lumpur, 1990, p. 32. 
tailor, ${ }^{19}$ a porter and a mechanic. Ijārah is similar to the third type of services being protected under the CPA.

Thus, for the purpose of comparison, the rules governing istisn $\bar{a}^{c}$ and ijärah will be referred to evaluate the extent to which Islamic law provides for better protection.

\section{THE LIABILITIES OF SERVICE PROVIDERS UNDER THE CONSUMER PROTECTION ACT 1999}

Section 53 provides that where services are supplied to a consumer, "there shall be implied a guarantee that the services will be carried out with reasonable care and skill." However, the section does not elaborate on the degree of care and skill required. It is reasonable to assume that the standard of care and skill expected is similar to the standard required under the law of negligence. This has been confirmed in the New Zealand case of Jetz International Ltd $v$ Orams Marine Ltd.,$^{20}$ in which Lord J Cadenhead held that the statutory duty in section 28 of the Consumer Guarantee Act $1993^{21}$ is similar to that prescribed by the common law in contract and tort. Therefore, the CPA does not introduce any change to the law of negligence and no doubt the common law cases in this respect play an important part in interpreting section 53. As such, the same problems which exist under the law of negligence will remain. The success of each case is objectively determined by the reasonableness of the supplier's conduct according to the ordinary level of skill, competence and diligence of other suppliers who are specialised in the same field. ${ }^{22}$ The difficulty for consumers is that in many situations they are ignorant of the practice in the industry in order to successfully prove that the service is defective.

\footnotetext{
$19 \quad$ A tailor can fall under the contract of istișnā if he uses his own material. However, if he uses the material given by the customer, the transaction falls under the contract of hire.

20 [1999] DCR 831.

21 This provision under the CGA is similar to section 53 of the CPA.

22 Mc Nair J., Bolam v Friern Hospital Management Committee [1957] 2 All E.R. 118 at 121, [1957] 1 W.L.R. 582 at 586; as approved in Whitehouse v Jordan [1981] 1 All E.R. 267 and also in Caparo Industries Plc v Dickman [1990] 2 W.L.R. 358.
} 
Section 54 of the CPA, on the other hand, provides that:

"Where services are supplied to a consumer, there shall be implied a guarantee that the services, and any product resulting from the services, will be -

(a) reasonably fit for any particular purpose; and

(b) of such nature and quality that it can reasonably be expected to achieve any particular result, that the consumer makes known to the supplier, before or at the time of the making of the contract for the supply of the services, as the particular purpose for which the services are required or the result that the consumer desires to achieve."

This implied guarantee as being provided under section 54 is very significant in the supply of services since it supposedly provides more than what is provided under common law. It can be seen in Thake $v$ Maurice,${ }^{23}$ in which the Court of Appeal held that there was no implied guarantee to ensure that a sterilisation by vasectomy would lead to sterility. Therefore, the surgeon was not liable when the patient became pregnant. By referring to section 54, the surgeon could be held liable since he had failed to achieve the particular purpose that has been made known by the consumer. The CPA has clearly changed the common law approach by imposing strict liability in situations where previously there would have no liability without proof of negligence.

However, a major shortfall of this guarantee is the concept of 'reasonableness,' being the key factor in determining its application. The Courts have to determine whether the services are 'reasonably' fit for any particular purpose and of such nature and quality that it can "reasonably" be expected to achieve any particular result. This requirement merely restates the common law standard. To quote Lord Denning's reasoning in Greaves \& Co. (Contractors) Ltd: ${ }^{24}$

$23 \quad$ [1986] 1 All E.R. 497. See also Greaves \& Co (Contractors) Ltd v Baynham, Meikle \& Partners [1975] 3 All E.R. 99.

$24 \quad$ Greaves \& Co. (Contractors) Ltd v Baynham Meikle \& Partners [1975]3 All E.R. 99. 
"It has often been stated that the law will only imply a term when it is reasonable and necessary to do so in order to give business efficacy to the transaction; and indeed, so obvious that both parties must have intended it..... In the great majority of cases it is no use looking for the intention of both parties. If you asked the parties what they intended, they would say they would never give a thought; or if they did, the one would say that he intended something different from the other. So the courts imply- or as I would say, impose a term such as is just and reasonable in the circumstances...”25

Consequently, if a consumer asks a supplier to perform certain services and he has made known his intended results, the liability of the supplier is only to perform services which are reasonably fit for that particular purpose. If that particular purpose is a 'folly,' the supplier can exclude liability by claiming that he has done whatever is reasonably expected from him. As such, this guarantee does not put liability on suppliers to guarantee the result in all situations. It seems unfair to the consumers because they have told the suppliers their intended outcomes and usually the price has been fixed based on their expectation. The supplier should be responsible to achieve the intended outcome once he has agreed to that task no matter how unreasonable the expectation is.

It can be seen in one New Zealand case, $W v L,{ }^{26}$ in which the defendant, a surgeon specialising in plastic and reconstructive surgery, made several representations that the operation would enhance the plaintiff's breasts to approximately a size "C." The plaintiff was dissatisfied with the result and the defendant claimed that the size of the breasts was the best he could obtain. The plaintiff had another operation with another surgeon and only then she discovered that the implants were underfilled and this was the reason why she couldn't get the expected outcome. In this case, she succeeded in her action to claim damages under section 28 and 29 of the New Zealand Consumer Guarantee Act 1993. ${ }^{27}$ This case shows that there was no difference in proving

\footnotetext{
$25 \quad$ Ibid., p. 104.

26 [1997]DCR588.

$27 \quad$ Section 28 and section 29 of the CGA are similar to section 53 and 54 of the CPA.
} 
guarantees under both sections because it was not a duty of the suppliers to guarantee the desired result unless there was the element of negligence.

Section 58 also provides several defences that hinder the effectiveness of section 54 in giving protection to consumers. It provides that if the failure is due to the act, default, omission or any representation made by a person other than the supplier ${ }^{28}$ or a cause independent of human control $^{29}$ no right of redress can be taken against the supplier. The issue would arise if the work is subcontracted to the sub-contractors and the default is caused by them. The consumer cannot obtain relief from the supplier because of the exceptions in section 58 which provides a defence in a situation where the failure is due to other people. ${ }^{30}$ This may include a consumer himself.

These exceptions make the protection under section 54 weaker compared to the implied guarantee provided under section 53 and also under common law. In Stewart $v$ Reavell's Garage, ${ }^{31}$ the Court held that the defendants were liable for the failure caused by their subcontractor. In this case, the particular purpose of the work which the plaintiff contracted to have done was obvious, namely, to be provided with an efficient braking system for his Bently car, which was a car specially designed for speed, and therefore required a braking system adequate for such speed. The Court held that the repairers were under a duty to provide good workmanship, materials of good quality and a braking system fit for its purpose, and not merely to employ competent sub-contractors. Unfortunately, the same result may not be achieved under the CPA because of the exceptions in section 58 .

\section{THE LIABILITIES OF SERVICE PROVIDERS UNDER ISLAMIC LAW}

The services are not in existent at the time when the parties enter into the contract and thus it will lead to uncertainties (gharār)

\footnotetext{
$28 \quad$ Section 58(a) of the CPA.

29 Section 58(b).

30 Nevertheless, the consumer can sue the sub-contractor because he is also a supplier as defined in section 3 of the CPA.

31 [1952]All E.R. 1191.
} 
which is not conducive for consumer protection. Istisnn $\bar{a}$, for example, is a contract of sale of specified items to be manufactured and as such the subject matter is not in existence at the time of the contract. Even though the majority have recognised the needs for this contract and allow the strict rule regarding the existence of the subject matters to be relaxed, they have acknowledged that there is uncertainty (gharār) in the istisnn $\bar{a}^{c}$ transaction. ${ }^{32}$ Therefore, Islamic law requires that the object to be manufactured is an object of sale, which must be well defined with respect to quality, quantity and other relevant characteristics. ${ }^{33}$ It is the obligation of the supplier to manufacture the goods according to the agreed specification. Upon delivery, there is an option (khiyār) in which the consumer may either take or reject the products as he thinks fit ${ }^{34}$ due to the reason that the subject matter did not exist at the time of the contract. The supplier of services, however, has no similar option.

As far as ijärah is concerned, ajīr mushtarak ${ }^{35}$ will be responsible for any damage caused due to his fault either on purpose or through negligence. ${ }^{36}$ If there is any fault or negligence that causes loss

$32 \quad$ Ahmad Hidayat Buang, "Unsur-unsur dalam pembentukan kontrak di dalam undang-undang Islam” vol. 2, no. 1 (1994) Journal Shariah 96, p. 98.

Mohd Zulkifli Muhammad \& Rosita Chong, "The contract of Bay'Alsalam and istișnā' in Islamic commercial law: A comparative analysis," Labuan e-Journal of Muamalat and Society, vol.1, 2007, p. 21-28; Wahbah al-Zuhailī, al-Fiqh al-Islāmī wa-ādillatuhū, vol. iv, translated by Md Akhir Haji Yaacob, Dewan Bahasa dan Pustaka, Kuala Lumpur, 1995, p. 649.

34 Liaquat Ali Khan Niazi, Law of contract, Ali Khan Niazi Research Cell, Dyal Sing Trust Library, 1991, p. 218. Nevertheless, Abū Yūsof was in the opinion that the consumer cannot reject the goods upon delivery, if it has been manufactured according to the agreed specification. Wahbah al-Zuhailī, al-Fiqh al-Islāmī wa-ädillatuhū, vol. iv, translated by Md Akhir Haji Yaacob, Dewan Bahasa dan Pustaka, Kuala Lumpur, 1995, p. 651.

35 As regards to ajīr khāss, his liability is like a custodian. When the property is destroyed in his hands without his working on it or without wrongdoing, there is no compensation. He will not be responsible even he makes mistake in relation to the work done. Nevertheless, this type of services is not covered under the CPA.

See for example Wahbah al-Zuhailī, al-Fiqh al-Islāmī wa-ädillatuhū, vol. iv, translated by Md Akhir Haji Yaacob, Dewan Bahasa dan Pustaka, 
of value of the product of services or destruction to the property, compensation becomes necessary. ${ }^{37}$ Imām Shāfi ' $\overline{1}$, stated that if the subject matter of services is lost in the supplier's possession, he will be responsible for the loss unless he can prove that he has taken good care of it. ${ }^{38}$ The supplier will be responsible irrespective of whether the damage happened in the presence of the consumers or in his absence; at the premises of the consumers or at the supplier's. ${ }^{39}$

The supplier cannot give the subject matter of services, which is in his charge, into the custody of another without the owner's permission. If he does, and afterwards it is destroyed, he is responsible. ${ }^{40}$ Imām Hanbal went further by stating that the suppliers who embezzle or misappropriate the object in their possession not only commit the offence of theft but they are severely punishable by $H \bar{a} d d .{ }^{41}$ Such a supplier will also be responsible if he purposely breaches any condition imposed in the agreement since it will amount to an unlawful act. ${ }^{42}$

Kuala Lumpur, 1995, p. 773, Sharīf ibn 'Ali Sharīf, al-Ijārah al-wāridah 'ālā 'amāl al-insān, Dār al-Syurūq, Arab Saudi, 1980, p. 253; Article 609 of the Majallah al-Aḥkām al-'Ādliyyah.

See Liaquat, Law of Tort, Lahore Research Cell Dyal Sing Trust Library, 1988, p. 64; Article 607 of the Majallah al-Aḥkām al-' Addliyyah in which provides that if the property delivered to the supplier is destroyed due to his wrongful act, he must make compensation. Article 608 also provides that it is a wrongful act if the service is contrary to the order of the hirer, clearly given or signified. Muḥammad bin Idrīs Al-Shāfi 'î̀, Kitāb induk al-Imām al-Syafi ' $\bar{\imath}$ (alUmm), vol. 5, translated by Ismail Yakub Sh-Ma C.V. Faizan, Jakarta, 1982, p. 292.

39 Abī Muhammad Abdullah, al-Mughnī li ibn Qudāmah, vol. 5, Maktab Al-Riyaḍ Al-Ḥadīth, Riyaḍ Arab Saudi, 1981, p. 526; Abi Muhsin Abd al-Waḥid ibn Ismā' īl al-Riwayani, Majrūl madhhab fī furū‘ madhhab Imām Shāfi ' '̄ , vol. 9, Dār Ihyā̄' al-Turāth Al-'Arabī, Lubnan, 2002, p. 321 and 325.

40 Liaquat, Law of Tort, Lahore Research Cell Dyal Sing Trust Library, 1988, p. 64.

$41 \quad$ Ibid., 63.

$42 \quad$ Wahbah al-Zuhailī, al-Fiqh al-Islāmī wa-ādillatuhū, vol. iv, translated by Md Akhir Haji Yaacob, Dewan Bahasa dan Pustaka, Kuala Lumpur, 1995, p. 774: Article 608 of the the Majallah al-Ahkām al- 'Ádliyyah. 
However, there are disagreements among the Muslim jurists in relation to the obligations of ajir mushtarak in situations where there is no evidence of bad intention or negligence. Abū Yūsuf and Muḥammad, Abī Laylā ${ }^{43}$ and one view of Imām Shăfi ' ${ }^{44}$ are of the opinion that the obligations of ajìr mushtarak are damān. ${ }^{45}$ They are liable for what is destroyed in their possession caused by the acts of other people even if there is no bad intention or negligence on their part unless evidence is adduced to show that the destruction is caused by factors beyond their control. ${ }^{46}$ The rule in Imām Malik's opinion is that the suppliers will compensate all that is caused at their hands like fire, breakage of the article when they are working in their own shops, even if the owner is standing next to them, except where the risk is inherent in the work such as the burning of bread by the baker. ${ }^{47}$ Imām Abū Hanīfah made a

$43 \quad$ Sayid Sabiq, Fikih Sunnah, vol. 13, translated by H. Kamaluddin A. Marzuki, Victory Agencies, Kuala Lumpur, 1990, p. 33; Ibn Rushd, Bidāyah al-Mujtahìd., vol. 2, translated by Imran Ahsan Khan Nyazee, Garnet Publishing Limited, United Kingdom, 1996, p. 278; Wahbah alZuhailī, al-Fiqh al-Islāmī wa-ädillatuhū, vol. iv, translated by Md Akhir Haji Yaacob, Dewan Bahasa dan Pustaka, Kuala Lumpur, 1995, p. 771; Sharīf ibn 'Ali Sharîf, al-Ijārah al-wāridah 'ālà 'amāl al-insān. Dār Al-Syurūq Arab Saudi, 1980, p. 253. Muḥammad bin Idrīs Al-Shāfi 'î̀, Kitāb induk al-Imām al-Syafi 'ci (alUmm), vol. 5, translated by Ismail Yakub Sh-Ma C.V. Faizan, Jakarta, 1982, p. 290. However, Ibn Ḥazm, Zufar, Imām Al-Shāfi 'ī and one opinion of Ḥanbalis argued that ajìr mushtarak is a custodian like ajīr khāsș. His position is similar like the partner and the agent. He will not be responsible unless he neglects or has intention to cause it. See Wahbah al-Zuhailī, al-Fiqh al-Islämī wa-ādillatuhū, vol. iv, translated by Md Akhir Haji Yaacob, Dewan Bahasa dan Pustaka, Kuala Lumpur, 1995, p. 771; Sharif ibn 'Ali Sharīf, al-Ijārah al-wāridah 'ālā 'amāl al-insān. Dār alSyurūq, Arab Saudi, 1980, p. 255; Sayid Sabiq, Fikih Sunnah vol. 13, translated by H. Kamaluddin A. Marzuki, Victory Agencie, Kuala Lumpur, 1990, p. 33; Abi Muhsin Abd al-Wahid ibn Ismā'̄îl al-Riwayani, Majrūl madhhab fī furū' madhhab Imām Shäfi 'ì, vol. 9, Dār Ihyā' alTurāth Al-'Arabī, Lubnan, 2002, p. 322. al-Syurūq, Arab Saudi, 1980, p. 254 and 255.

$47 \quad$ Ibn Rushd, Bidāyah al-Mujtahìd., vol. 2, translated by Imran Ahsan Khan Nyazee, Garnet Publishing Limited, United Kingdom, 1996, p. 279. 
distinction between working for wages and not working for wages. If he takes possession for wages, then the benefit accrues to both contracting parties and therefore the supplier has to be responsible for any damage. ${ }^{48}$ They came to this ruling on the basis of mașlahah and sadd al-dharäi ${ }^{\circ}$ a in order to protect the consumers' rights as a whole and to prevent suppliers from taking their responsibilities lightly. ${ }^{49}$ They also relied on the hadīth of the Prophet (s.a.w):

"He who takes will be responsible until he returns
it" 50

It had also become the practice of Khulafā Al-Rāshīdīn especially Imām 'Alī (ra) and Imām 'Umar (ra) to impose strict obligations on the supplier of services. ${ }^{51}$ Ibn Qudāmah had differentiated the obligations of ajīr mushtarak and ajīr khäss in which the responsibilities of the latter depends on the period of services not the services itself. However, the responsibilities of ajir mushtarak related to the performance of services and his wages depends on the work being supplied to the consumers failing which he would be responsible for the failure. ${ }^{52}$ This opinion clearly protects consumers' rights since the suppliers have to take full responsibilities for the subject matter or product of services.

The supplier is also responsible if he makes a mistake in carrying out his work even though the mistake is genuine without any evidence of bad intention or negligence. This is because, though the mistake constitutes

\footnotetext{
$48 \quad$ Ibid., 278.

49 Sharīf ibn 'Ali Sharīf, al-Ijārah al-wāridah 'ālā 'amāl al-insān. Dār al-Syurūq, Arab Saudi, 1980, p. 257.

$50 \quad$ Mālik, Muwattă', book 36, chapter 17.

51 Imām 'Alī (ra) gave this responsibility to a dyer, a washer, a barber, a tailor and the like. See Abī Muhammad 'Abdullah, al-Mughnì li ibn Qudāmah, vol. 5, Maktab Al-Riyaḍ Al-Ḥadīh, Riyaḍ Arab Saudi, 1981,

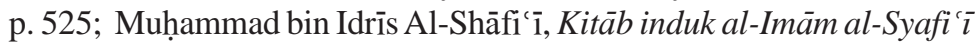
(al-Umm), vol. 5, translated by Ismail Yakub Sh-Ma C.V. Faizan, Jakarta, 1982, p. 291; Sharīf ibn 'Ali Sharīf, al-Ijārah al-wāridah 'ālā 'amāl alinsān. Dār al-Syurūq, Arab Saudi, 1980, p. 257.

52 Abī Muhammad 'Abdullah, al-Mughnī li ibn Qudāmah, vol. 5, Maktab Al-Riyaḍ Al-Ḥadīh, Riyaḍ Arab Saudi, 1981, p. 525.
} 
a ground of defence, it is not an excuse as far as the rights of people are concerned $^{53}$ i.e the consumers. For example, instead of repairing the vehicle, a mechanic causes its condition to deteriorate. This is the opinion of the Hanbalîs which states that the supplier will be responsible for his mistake irrespective of whether it happens in the presence of the consumers or not; or at the places of the suppliers or the consumers. ${ }^{54}$ The Majalllah al-Ahkām al-'Adliyyah states that the supplier will be responsible if the object is destroyed due to his act even done unintentionally. ${ }^{55}$ Hanafī and Hanbalī jurists and one group of Shāfî̀ is are of the opinion that the suppliers will be responsible for their mistake if the work is carried out at their places without the presence of the consumers. $^{56}$ This is because their wages will depend on their performance of the work and it must be delivered to the consumers as agreed.

Therefore, by referring to the rulings under Islamic law, very strict obligations have been imposed on the service providers. They will be responsible for all damage irrespective of whether they purposely commit it or not; either cause by their negligent act or by mistake. These support the argument that Islamic law places great emphasis on consumers' rights in their transactions. The protection available is also greater compared to the protection under the CPA which only imposes liability on the service provider to carry out his work with reasonable care and skill.

In respect of negligence, Islamic law imposes strict obligations on the service providers to the extent that the jurists of all schools make

53 Zaleha Kamaruddin, Strict liability in criminal law. A comparative approach, Nurin Enterprise, Kuala Lumpur, 1988, p. 61.

54 Sharīf ibn 'Ali Sharīf, al-Ijārah al-wāridah 'àlā 'amāl al-insān. Dār al-Syurūq, Arab Saudi, 1980, p. 260.

55 Article 706 and Article 707 provide that if the damage was caused by his mistake, the person will be responsible.

56 However, if the work is performed in the presence of the consumers or at their places, there is no such obligation since the vehicles are still in the possession of the consumers. Therefore, the liability is similar to ajīr khāșs. See Sharīf ibn 'Ali Sharīf, al-Ijārah al-wāridah 'ālā 'amāl al-insān. Dār al-Syurūq, Arab Saudi, 1980, p. 260; Abī Muḥammad 'Abdullah, al-Mughnī li ibn Qudāmah, vol. 5, Maktab Al-Riyaḍ AlHadīh, Riyaḍ Arab Saudi, 1981, p. 526. 
the suppliers liable for their acts of negligence. ${ }^{57}$ The duty imposed on the supplier is more stringent from that of trust, in which the supplier is absolutely liable for the loss, and inevitable accident cannot be accepted as a defence. ${ }^{58}$ This is because the supplier has a moral and ethical duty to take care of the rights of other people and he has to discharge his duty to the best of his capabilities. This obligation can be seen in various divine verses of the Holy Qur'ān and the saying of the Prophet (s.a.w). Among the examples are:

"And serve Allah, and join not any partners with Him; And do good to parents, kinsfolk, orphans, those in need, neighbours who are of kin, neighbours who are strangers, the companions by your side, the way-farer and what your right hands possess; For Allah love not the arrogant, the vainglorious." 59

The hadīth of the Holy Prophet says:

"Anybody who believes in Allah and the last day should not harm his neighbour." 60

In respect of the onus of proof, the liability under Islamic law is determined by looking at the damage ${ }^{61}$ and the defendant is held liable if

57 See for example Wahbah al-Zuhailī, al-Fiqh al-Islāmī wa-ādillatuhū, vol. iv, translated by Md Akhir Haji Yaacob, Dewan Bahasa dan Pustaka, Kuala Lumpur, 1995, p. 773; Sharïf ibn 'Ali Sharīf, al-Ijārah al-wāridah 'àlā 'amāl al-insān. Dār al-Syurūq, Arab Saudi, 1980, p. 253; Muḥammad bin Idrīs Al-Shāfi ' '̄i, Kitāb induk al-Imām al-Syafi ' $\bar{\imath}$ (alUmm), vol. 5, translated by Ismail Yakub Sh-Ma C.V. Faizan, Jakarta, 1982, p. 292.

58 Mohammad Muslehuddin, Concepts of civil liability in Islam and the law of torts, First edition, Islamic Publication Pakistan, 1982, p. 59.

Al-Qur'ān, Sūrah Al-Nisā’ 4:36.

Al-Bukhārī, Saḥịh, kitab viii, Chap. 28.

The defendant is liable for legal damage only under common law which is the invasion of plaintiff's legal right which is created by law. Nevertheless, he will be liable for actual damage under Islamic law. See Mohammad Muslehuddin, Concepts of civil liability in Islam and the law of torts, First edition, Islamic Publication Pakistan, 1982, p. 79. 
the damage is the direct result of his act irrespective of whether the act is intentional or accidental, ${ }^{62}$ or whether he can reasonably foresee it or not. ${ }^{63}$ This is because civil liability in Islam is not 'fault liability' or 'strict liability' ${ }^{64}$ but it can be described as 'damage liability.' 65 This ruling is good for consumer protection since they are required only to prove damage and the burden is on the suppliers to prove otherwise. This will overcome the hindrance to prove liabilities under the CPA which requires a consumer to prove various complex elements in establishing the supplier's fault. ${ }^{66}$ The central argument is that it is extremely difficult for consumers to prove that suppliers are at fault in the case of damage whereas the latter with technical knowledge at their disposal can provide proof to the contrary more easily.

\section{CONSUMERS’ RIGHTS OF REDRESS}

Part IX ${ }^{67}$ of the CPA provides rights of redress to consumers. In the case where the failure is one that can be remedied, the consumer may require the supplier to remedy a defect within a reasonable time ${ }^{68}$ and claim damages. ${ }^{69}$ However, if the failure is one that cannot be

\footnotetext{
$62 \quad$ Ibid., 53.

$63 \quad$ Ibid., 79.

64 Under Islamic laws, strict liability is the exceptional principle in which the penal punishments may be awarded for an act if the public interest so requires, even though such an act may not in itself be a crime as defined by the sharī'ah with no injunction declaring it unlawful. See Zaleha Kamaruddin, Zaleha Kamaruddin, Strict liability in criminal law. A comparative approach, Nurin Enterprise, Kuala Lumpur, 1988, p. 34.

65 Mohammad Muslehuddin, Concepts of civil liability in Islam and the law of torts, First edition, Islamic Publication Pakistan, 1982, p. 53. It is particularly difficult to prove the breach of duty and its causal link with the loss suffered by consumers.

67 Part IX provides a new set of statutory remedies in line with the remedies provided by the Sale and Supply of Goods to Consumers Regulations 2002 (UK) in which Regulation 9 contains provisions which insert six new sections, $11 \mathrm{M}$ to $11 \mathrm{R}$, into the Supply of goods and Services Act 1982.

68 Section 60(1)(a) of the CPA.

69 Section 60(2).
} 
remedied or is one of substantial character, the consumer can cancel the contract or obtain from the supplier damages in compensation for any reduction in the value of the product resulting from the services below the charge paid or payable by the consumers for the services. ${ }^{70}$

The CPA brings the law in line with reality by giving consumers the remedy that they really want; namely to remedy the defect within a reasonable time. Previously, this remedy was a matter of business practice rather than the law. ${ }^{71}$ This remedy is advantageous to both parties since the consumer obtains what he has originally contracted for and the supplier eventually obtains the full price. It will also solve the problems of putting a monetary value on 'consumer surplus' which is very speculative. ${ }^{72}$

Nevertheless, in some circumstances, it seems unfair to compel a consumer to return to the original supplier to remedy the defects especially in a situation where the consumer has a previous bad experience with the supplier. It can be seen in the New Zealand case of Norton $v$ Hervey Motor $\mathrm{Ltd}^{73}$ where the plaintiff wanted to reject the goods and refused to allow the defendant to repair the failure. In this case, the plaintiff had previously purchased a Commodore from the defendant and when the vehicle was returned for a service check, its paintwork was accidentally damaged. She was not satisfied with the repair work and a dispute arose. In an attempted resolution, she agreed to purchase a Nissan Navara. However, after 10 days of taking delivery of the

\footnotetext{
$70 \quad$ Section 60(1)(b).

71 Under the law of contract, the remedy of specific performance is only awarded in very limited cases where the courts find that damages are inadequate. The law on specific performance is found in section 11-29 of the Specific Relief Act 1950.

72 Unlike the businessperson who seeks a profit, and therefore the damages can be ascertained with exchange-value, a consumer usually buys things for use, and therefore is concerned with use-value. For example, wedding photographs are worth more to the couple than the cost. The courts usually face problems to put the figure on this 'consumer surplus.' By awarding the remedy of 'remedying the defect' they can avoid the difficulty of trying to put a monetary value on the surplus. For further discussion see Donald Harris, David Campbell and Roger Halson, Remedies in contract and tort, 2nd. Edition, Butterworths Lexis Nexis, 2002, p. 168-171.

73 [1996] D.C.R. 427.
} 
Navara, she noticed defects in the vehicle's paintwork. Recalling her previous experience with the defendant, she decided to reject the car. The Court held that the existence of a warranty to repair the defect was readily enforceable and cannot be ignored at the plaintiff's option. The decision seems unfair to the consumer since she has to deal with the same supplier with whom she has lost confidence. It appears that the choice of remedy is not left to consumer to decide. Even if the failure is substantial, section 62 of the CPA provides an opportunity to the supplier to remedy the defect within a reasonable time. It seems that the CPA provides a weaker remedy compared to the remedy under the law of contract which enables the aggrieved party to repudiate the contract if the breach is substantial (breach of condition) without giving option to the supplier to remedy the defect.

Comparatively, the Islamic law provides a better approach in protecting consumers. Hanafīs and Hanbalīs give greater protection to consumers to the extent that they can choose the remedies that they desire. They can choose either to accept the defective services but the wages are reduced or pay wages subject to a claim for compensation based on the difference between the contract price and the market price at the date of failure. ${ }^{74}$ The basis for this priority is because the consumer is the owner of the subject matter and he is entitled to any losses in relation to his property. ${ }^{75}$ Nevertheless, the compensation should not be greater than the damage suffered and cannot be as a means of punishment. Allah swt says to the effect:

“The recompense for an injury is an injury equal thereto.”76

Similarly if the supplier performs more than the agreed task, the jurists including Imām Shāfi 'i grant consumers the option (khiyār) to either continue with the agreement or to rescind it. If he wishes he can

Sharīf ibn 'Ali Sharīf, al-Ijārah al-wāridah 'ālā 'amāl al-insān. Dār al-Syurūq, Arab Saudi, 1980, p. 269; Abī Muhammad 'Abdullah, alMughn̄̄ li ibn Qudāmah, vol. 5, Maktab Al-Riyaḍ Al-Ḥadīh, Riyaḍ Arab Saudi, 1981, p. 528.

75 Sharīf ibn 'Ali Sharīf, al-Ijārah al-wāridah 'ālā 'amāl al-insān. Dār al-Syurūq, Arab Saudi, 1980, p. 269 and 270.

76 Al-Qur'ān, Sūrah al-Shūrā 42:40. 
accept the work on the supplier's expenses. ${ }^{77}$ The same ruling is applicable if the supplier performs contrary to the order of the consumer and the disparity is in relation to the types of work. For example; instead of doing alignment and balancing of the wheels, the garage performs radiator service. In this situation, the consumer will have the option either to claim compensation or accept the work and pay according to the equivalent price (ajr al-mithl). ${ }^{78}$

If the disparity is in relation to the 'attribute' of the work, the consumer will also entitle to an option (khiyār) either to claim compensation for the damage done or accept the work and pay according to the equivalent price. ${ }^{79}$ For example, if the consumer asked the garage to paint the car red but the workman painted it yellow, the supplier is not entitled for the agreed price (ajr al-musammāa). If the disparity is in relation to the quality of the work, the right of consumers will prevail. For example, if the garage used spare parts which were of low quality compared to the agreed one, the consumer need only pay the price according to the spare parts used and not the agreed price. Similarly even if the garage used better quality spare parts, he is not entitled to the agreed price. ${ }^{80}$ The same principle is applicable in the contract of istișn $\bar{a}$, in which the right of option (khiyär) is also applicable to consumers. They may either take or reject the products as they think fit $^{81}$ due to the reason that the subject matter did not existed at the time of the contract. The supplier of services, however, has no similar option and he can be compelled to do the work. Therefore, the Islamic law rulings give advantage to consumers to the extent that they can choose the remedies that they desire by exercising their right of option (khiyār). The same advantage, though, is not available under the CPA.

77

Muḥammad bin Idrīs Al-Shāfi ' ‘̄, Kitāb induk al-Imām al-Syafi ‘ $̄$ (alUmm), vol. 5, translated by Ismail Yakub Sh-Ma C.V. Faizan, Jakarta, 1982, p. 275.

Wahbah al-Zuhailī, al-Fiqh al-Islāmī wa-ādillatuhū, vol. iv, translated by Md Akhir Haji Yaacob, Dewan Bahasa dan Pustaka, Kuala Lumpur, 1995, p. 778.

Ibid.

Wahbah al-Zuhailī, al-Fiqh al-Islāmī wa-ādillatuhū, vol. iv, translated by Md Akhir Haji Yaacob, Dewan Bahasa dan Pustaka, Kuala Lumpur, 1995, p. 778.

Liaquat Ali Khan Niazi, Law of Contract, Ali Khan Niazi Research Cell, Dyal Sing Trust Library, 1991, p. 219. 


\section{CONCLUSION AND SUGGESTION}

The above discussion shows that Islamic law has imposed very strict obligations on the service providers in which they have to be responsible for all damage caused irrespective whether they have purposely committed it or not; either caused by their negligence act or by mistake. The liability is determined by looking at the damage. As such, the supplier is liable if the damage is the direct result of his act irrespective of whether the act is intentional or accidental, or whether he can reasonably foresee it or not. This ruling is good for consumer protection since they are required only to prove damage and the burden is on the supplier to prove otherwise.

It is submitted that the same approach should be incorporated into the CPA. The standard of reasonable care and skill as being provided under the CPA is too lenient in which the supplier can escape liability by claiming that he has done his work with care and the failure is due to the fault of other people or a cause independent of human control. Consequently, there is no guarantee that the service which has been done with care and skill is of high quality and safe.

In addition, consumers relying on section 53 of the CPA, will face problem to successfully prove that the service is defective since on most occasions they are ignorant of the practice in the industry. In order to overcome this problem, the suggestion is to reverse the evidentiary burden to the suppliers. As such, consumers will only required to prove the defective services and the burden is on the suppliers to prove otherwise, which is in line with the Islamic law approach.

As far as the remedies are concerned, it is submitted that more options should be given to consumers in determining the remedies that they really want. The remedy provided in section 60(1)(a) of the CPA, namely to remedy the defect, should be given to consumers as a matter of options rather than being the principal remedy. Let the consumers decide either to allow the same supplier to repair the defect or go to the other suppliers and then claim from the former the payment for making good of that defect. The right of option (khiyār) as provided by Islamic law is more favourable to consumers. Therefore, the CPA should adopt this principle so as to strengthen the consumer protection in the country. 
Consumer Protection the the Supply of Services 